\title{
Investigating what Determines Strategic Issues in Organizations: A Qualitative Study
}

\section{Bahareh Abedin}

\author{
PhD candidate in strategic management, faculty of Management and Econimics, Tarbiat Modares University, Tehran, Iran \\ b.abedin@modares.ac.ir
}

\author{
Asadollah Kordnaeij \\ Associate Professor, Faculty of Management and Economics, Tarbiat Modares University, Tehran, Iran \\ naeij@modares.ac.ir
}

Hasan Danaee Fard

Professor, Faculty of Management and Economics, Tarbiat Modares University, Tehran, Iran hdanaee@modares.ac.ir

\section{Seyed Hamid Khodadad Hoseini}

Professor, Faculty of Management and Economics, Tarbiat Modares University, Tehran, Iran khodadad@modares.ac.ir

\section{Doi:10.5901/mjss.2015.v6n5s2p553}

\section{Abstract}

Research shows that there is currently a lack of a systematic way to identify strategic issues in organizations. While several factors have been reported to show significance or insignificance of a strategic issue, more research is still needed to understand how strategic decision-makers determine strategic issues faced by the organization and also how these issues are diagnosed. This becomes important as effective determination of strategic issues influences decision maker's agenda and priorities. Thus, this paper conducts 21 in-depth interviews with banking experts in Iran. Data analysis is done through grounded theory methodology. The findings of this study show that there are six groups of factors that affect issues to give the meaning of strategic for top managers of organization.

Keywords: Strategic issue, Grounded Theory methodology

\section{Introduction}

Strategic issues refer to events, developments, or trends which largely influence the performance of an organization (Ansoff, 1980). According to Daft and Weick, strategic issues are social structures created in organizational context (Weick, 1979; Daft and Weick, 1984; Feldman, 1989; Weiss, 1989). Therefore, what is perceived as a strategic issue in an organization might be understood as a tactical or irrelevant issue in another organization. Due to the existed ambiguities such as lack of clear information (March and Olsen, 1976) and complicated meanings of strategic issues (Weick, 1979), it is necessary to recognize specific factors that shape strategic issues. When an issue is recognized as a strategic issue, organization's strategic resources and information processing capacities are allocated to them, which considerably influence the organization's achievement or failure.

\section{Research Problem}

The key problem this research aims to address is that a lack of clear understanding of what is actually going on in the organizations which lead to considering an issue as a strategic issue. Lacking of such understanding causes increased management errors in prioritization of strategic which may affect organizations' future performance. Therefore, it is important to identify these factors through better understanding the organizational environment. Thus, the research main question is what are the key factors that lead to an organizational issue to be considered as a strategic issue in an 


\section{organization?}

\section{Strategic Issues Definition}

According to Meyer (2007), a strategic issue is an analytically distinct sub-system of a strategic problem, pertaining to a specific topic. In addition, Birkelund (2003) asserts that deduction domain of a strategic issue could be broad, disperse, and unclear, especially in early stages. Because it is not predefined, some perceptions or assignment of the meaning to these issues are required to design, select, and apply a solution for them.

\section{Review of the Literature}

For better understanding of strategic issues and factors that affect them to give the meaning of strategic, three main areas of the literature have been reviewed. Each of these areas is related to activities that cover from the phase of environmental evaluation and strategic issue identification up to their entrance into the organization's strategic agenda. These three areas are: environment evaluation, issue evaluation, and agenda building, which are described below.

\subsection{Environment evaluation}

Environment evaluation refers to activities based on which decision-makers examine, scan, and monitor the organization's environment (Miller, K. D., \& Lin, 2014; Dutlon et al., 1989). Aguilar (1967), defined environment monitoring as part strategic planning, as follows:

"About events and relationship in a company's outside environment, the knowledge of which would assist top management in its task of charting the company's future course of action."

Like other organizational activities, the environmental monitoring process is effective on organizational perception. Heugens (2001) has stated that the perceptual selection process indicates how organizations high-level decision-makers assign their limited cognitive capabilities to particular strategic issues. He argues that two modes of environmental scanning exist: passive scanning and prospective scanning.

The purpose of prospective scanning is to determine issues that are still incomplete, thus they warn the organization about potential issues. The other mode of environmental scanning is passive in nature. In this mode, organizations pay attention to issues when the issues have actually happened. Organizations choose one of these scanning modes with regards to the managerial understanding about organizational position in the environment (Motii \& Sanders, 2014).

\subsection{Issues evaluation}

Issues evaluation is associated with two concepts of interpretation and sense giving. Interpretation means the process of transforming the events, development of models for understanding, discovering the meaning, and cresting conceptual schemas among key managers (Fearon et al., 2012; Daft \& Weick, 1984). In the present study, like the study by kunnas (2009), the interpretation has been considered as a separate phase of environmental scanning. However, some investigations have defined interpretation as part of environmental scanning (e.g. Kiesler and Sproull, 1982: 548). Organizations can be considered as an interpretation system when they act as particular information receivers which interact with the environment. Organizations' differences in interpretation are rooted in: a) management ideas about analyzability of the external environment (Daft \& Mackintash, 1981) and b) the extent to which the organization permeates into the environment in order to understand it.

Daft and Weick (1984), claim that interpretation is different from sense making. However, sense making may sometimes encompass interpretation. In other words, Weick believes that sense making concerns the ways in which people offer their interpretations. In contrast, interpretation seeks to discover or approximate data. Thus sense making is more about invention rather than discovery. For participating in sense making of an issue, we should create, filter, frame, realize, and interpret its subjectivity to a more tangible concept. Thus the concept of sense making is valuable because it shows an invention that is superior to interpretation (from kunnas, 2009).

Activities which lie in this class of actions are related to strategic issue formation and are classified into two categories: a group which relates to sense making activities that are associated with issue diagnosis in the research 
literature; and a group which is related to sense giving activities that are associated with the strategic issue selling.

According to the definition by Thomas et al. (1993), sense making and sense giving are two supplementary and mutual processes. Sense making refers to the way based on which managers understand, interpret, and create meaning of the information available about strategic changes, whereas sense giving concerns their efforts for influencing outcomes, transferring their thoughts about the change to others and obtaining their support. The boundaries of these two processes are interwoven, and like discourse and practice, sense making and sense giving are less distinct such that one implies the other and their existence is not possible without each other (Rouleau, 2005).

In this respect, a number of researchers sought to find out how managers make sense of the past, encounter the present, and plan for future (Dunford \& Jones, 2000; Huisman, 2001; Jameson, 2001), and that how sense making and sense giving occur socially over time (Hopkinson, 2001).

\subsubsection{Strategic Issue Diagnosis}

Strategic issue diagnosis is a process during which managers give sense to the continual flow of ambiguous and complex environmental data, which determines the organization position (Kent \& Lin, 2014). Dutton and her colleagues (1983), believe that strategic decision-making is important and it influences the decision and selection processes and subsequently organizational performance (Fearon et al., 2012; Thomas, Clark, and Gioia, 1993). In other words, how managers diagnose environmental events and transformation is a vital issue because different diagnoses could lead to different strategic responses (Dutton and Dukerich, 1991; Gutton and Duncan, 1987; Lant, Milliken, and Batra, 1992).

Gilbert (2006) has stated that managers investigate their environment changes, interpret them, and label them according to cognitive mechanisms. He has acknowledged that CEOs' framing of environmental changes in terms of positive and negative terms affects organizational changes. Also, some diagnoses may be more effective on strategic decisions and they may result in higher levels of performance, than other diagnoses (Fearon et al., 2012, Gooding and kinicki, 1995).

From Dutlon's perspective (1970), there is a mutual relation between the manger and the environmental events and transformations in strategic issue diagnosis. In one hand, environmental transformations are partially in the form of objective realities that influence how issues are diagnosed and understood, limitations existing in this context, and how to take action about them. On the other hand, they are the managers that conform these transformations and events in their surrounding environment, interact with them, and shape them (Motii \& Sanders, 2014, Dutton, 1993).

Previous studies have attributed the strategic issue diagnosis to various organizational characteristics; for example, culture and the structure of strategy and information processing (Dutton and ottensmeyer, 1987; Thomas and McDaniel, 1990), the extent of diversity in the chief management team (Dutton and Duncan, 1987; plambeck and weber, 2009), resource dependencies (Milliken, 1990), and data processing (Olambeck and weber, 2010)

\subsubsection{Issue Selling}

Brown and Aisenhart (1997), show that organizations are pluralistic market of ideas, where issue are sold through managers' and individuals' persuasive efforts and are bought by chief managers who adjust the organization's strategic direction. In such a picture, effective management is achieved through proper understanding of the elements of the key process of issue selling.

When an strategic issue has been determined, a specific reasoning is required to be made by organizational participants to specify the excellence of the issue (Fearon et al., 2012). The process of strategic issue selling refers to activities that are performed to influence others' awareness in issue understanding. Issue selling could be considered as the main basis for the explanation of why and how superior managers assign their awareness and time to a particular issue (kunnas, 2009). In fact, issue selling refers to the process by which individuals influence on others' attention to events and on their understanding of events, transformations and trends related to the organization performance (Ansoff, 1980; Dutton and Ashford, 1993).

Dutton and Ashford (1993) and Field and Wooldridge (1996), assert that because any problem is not strategic by itself, individuals' claim about what is important (for example, issue selling) determines which change plan is activated in an organization (Dutton et al., 2001)

One of the main indicators concerning the success of issue selling is the amount of time and attention that superior manager devotes to an issue. Attraction of collective attention toward an issue is displayed by types of behaviors: (a) issue naming; (b) collecting data related to the issue; (c) talking about the issue; and (d) establishing role or task-force specific to the issue. 
Drawing the attention of the top management to strategic issues is a fundamental step towards assigning more resources to an issue. One of the group of people who could have an important role in moving an issue into the strategic agenda are the middle managers. Kaunter (1989), believes that the potential ability of middle managers is to influence the top managers' perception and strategizing (strategy-making) about a particular issue. Because the middle managers have the pulse of the organization performance, they can convince others and pose new ideas which may not be discovered by the superior managers.

\subsection{Agenda building}

Agenda building is about the steps in take for an issue to be entered into an organization's strategic agenda. The process of assigning attention to the strategic issues has been conceptualized as the agenda building process. According to Bower (1972) and Burgelman (1983), the agenda is not solely captured by the organization's superior decision-makers, but also it is the product of the forces from multiple levels in the organization, which consciously or unconsciously leads to an issue be legitimated, resources be assigned to that, and consensus be established about it (Motii \& Sanders, 2014).

By understanding the process of agenda building and its probable outcomes, people could manage it and thereby take advantage of it. For example, facilitating or limiting the entrance of an issue into the agenda is a robust tactic to make changes with particular intentions. Accordingly, by understanding how the agenda is formed, individuals can manage ambiguities existing about problem regulation (adjustment) in the organization (Metcalfe, 1981).

In summary, an organization's strategic agenda (Dutton, 1988) refers to a set of issues which has attracted superior organizational decision-makers in a particular point of time (Dutton \& Guncan, 1987). Also, assigning the organization's resource or information processing capacity to the issued is an important sign specifying that how capacity to the issues is an important sign specifying that how issue are embedded in agenda (Simon, 1971).

How an issue is named, how much time is devoted to, and how information is collected about that issue, indicate how managers' attention is assigned to such issues (Dutton, 1988, p.127).

\section{Research Methodology}

Research steps to obtain the conceptual model are as follows:

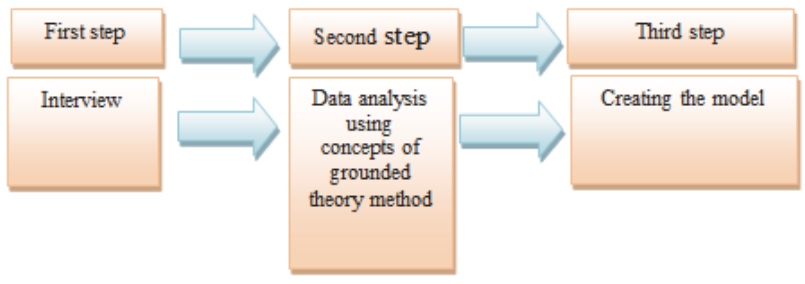

Figure 1: Steps of research

As this current research is an exploratory study, Glaser (1978) grounded theory method has been used to discover factors impacting on determining issues as strategic issues. This approach does not embrace any pre-defined hypotheses in grounded theory; rather seeking for participants' main concern and how to resolve this concern in the field study. In general, Glaser approach in grounded theory methodology can be achieved through three main coding steps. Coding moves the researcher, through breaking the data, from empirical level so that the data classified in codes turning into theory [8]. According to this approach, three main coding steps include: 1) Open coding; 2) Selective coding (the first and second steps called substantive coding); 3) Theoretical coding.

The current study has also followed these stages in order to obtain its objectives.

\section{Research Statistical Population and Sample}

The statistical population of this research is the Iranian banking industry experts selected through theoretical sampling method. Glaser (1978), suggests that it is the role of the researcher to select participating individuals and groups and 
then purposefully attempt sampling, as they are able to provide useful information in the chosen topic area.

Therefore, this research has conducted deep, semi-structured interviews with 21 Iranian bank experts with rich background and information about strategic decision making in the banking industry.

\section{Research Findings}

After conducting the interviews, the following main categories or factors influencing on identification of issues as strategic have been discovered: scanning, environmental monitoring, strategic dialogue, identifying potential important issues, screening, management context, organizational context, noises in the area of an issue, formation of strategic issues in the form of organization's agenda.

- Scanning: organizations depend on their environment often adapting to its dynamic and changing conditions. They can predict such environment evolutions based on early warnings.

- Environmental monitoring investigates how decision-makers determine and supervise outside environmental issues. Environmental monitoring indicates how managers consider environmental changes and alarms. The findings of the interviews demonstrated that managers perform this monitoring based on upstream documents such as Central Bank circulars, organization's statements like mission and vision statement, reports and letters of reference, etc.

- Identifying potential issues: this shows that identifying issues has a significant impact on organization's performance, which is determined by aspects such as problem content (its significance and clarity, etc.), its relation to other issues, and the related beneficiaries.

- Strategic dialogue: social interaction among players shape strategic dialogues around strategic issues. All members of an organization including players outside the organization's formal structure, who might be involved with strategic issues interactions, are potential players of the issue area. Strategic dialogue refers to all existing communications, debates, and discussions on strategic issues and the issue area is the venue of these measures (Hall et al., 2006). The term 'dialogue' means what is taking place in our interactions, "sustainable collective queries about processes, assumptions, and insurances making our daily experience." Dialogue enables players influence a set of events. It can be a real conversation between two or several actors and, at the same time, it can be a tense debate among coalitions of players with different opinions, views and ideas on strategic developments (Jacobs and Heracleous, 2005). Strategic dialogue occurs in different social contexts. For instance, in formal meetings like meeting of the Board of Directors and informal meetings whether inside the organization like the organization's hallways or outside the organization such as a meeting for dinner (from Mazzola et. al., 2010).

- Screening: it means distinguishing significant topics from insignificant ones, and or strategic issues from operational issues. By giving meaning to an issues, Screening means an evaluation of the issues' feasibility and prioritization.

- Management context: it includes factors such as managers' psychological aspects, values and ethics, management duration, as well as arrangement of senior executives influence screening issues in management context.

- Organizational context: factors such as organization's structure, organization's information processing system, and organizational atmosphere and culture in organizational context form influence screening issues.

- Parasites in the area of issues: it means interventions affecting screening action like gossiping, lobbying, and coalitions.

- Formation of strategic issues in the form of organization's agenda: the issues passed screening stage form the organization's strategic agenda succeeded in attracting management's time and attention. Figure 2, demonstrates the conceptual model of strategic issue shaping. 


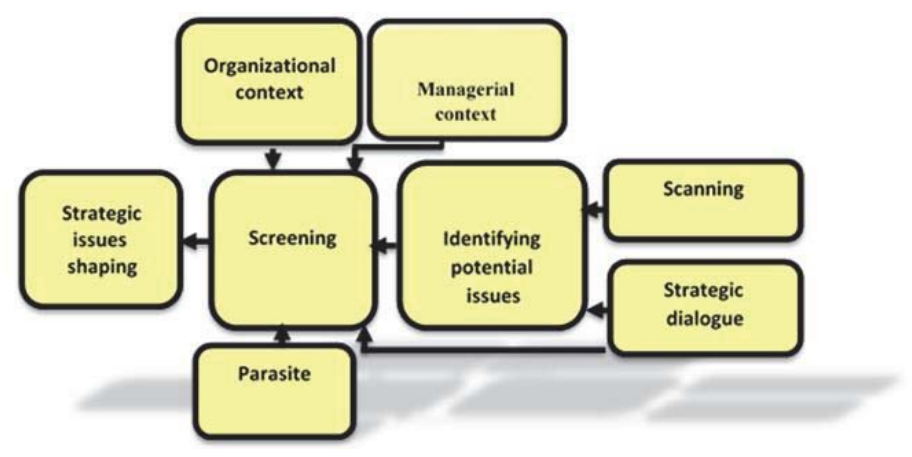

Figure 2: Key factors that give strategic meaning to organizational issues

\section{Conclusion}

This research discovered factors that impact on considering an issue as strategic issue in an organization to address the extended, scattered, and unclear deductive nature of strategic issues. Findings of this study reveal that senior executives initially look for monitoring the environment through reports, analyses and other environmental monitoring tools for identifying the issues, which may influence the organization's future performance considering the issues' various aspects.

In addition to environmental monitoring, other events also affect on identifying potentially important issues. Of the most critical factors are the dialogues formally or informally taking place around the issues, which may have long-term and substantial impacts on the organization. These dialogues can also be the source of some potentially important issues for the organization occurring under the influence of environmental monitoring leading to identifying potentially important issues.

Issues that are significant to managers are those that have potential in-depth effects on organization's future performance. They embrace aspects such as origin, content and type of relation with other organization's issues and beneficiaries associated with these issues.

The screening stage is an opportunity for both managers to employ their opinions in bringing issues to agenda and for other players of issue area to influence senior managers' opinions and or, in other words, the organization's key decision-makers by applying tactics. Furthermore, management context and organizational context influence screening stage mechanisms. On the other hand, available dialogues in issue context affect managers' view how screen potential critical issues. Therefore, each problem, in this stage, becomes significant during the process of sense making. An example of such problems is to understand opportunities or threats and to decide an appropriate action in regards to them. In summary, the result of this study leads to forming strategic issues, and determining which issues are important enough to be entered and discussed in an organization's strategic agenda.

\section{References}

Aguilar, FJ. (1967). Scanning the business environment, New York, NY: Macmillan.

Anderson, MH., Nichols ML. (2007). Information gathering and changes in threat and opportunity perceptions, Journal of Management Studies, 44: 367-387.

Anderson MH, Nichols ML. (2007). Information gathering and changes in threat and opportunity perceptions, Journal of Management Studies 44: 367-387.

Ansoff HI. (1980). Strategic Issue Management, Strategic Management Journal,1(2): 131-48.

Ashforth, B., Mael, F. (1989). social identitiy theory and the organization, Academy of management review, 14, 20-39.

Athukorala, P. C., \& Ekanayake, R. (2014). Repositioning in the Global Apparel Value Chain in the Post-MFA Era: Strategic Issues and Evidence from Sri Lanka (No. 2014-17).

Birkelund G. (2003). Strategic Issue Diagnosis as a Cultural Process of Paradox and Unobtrusive Power, doctoral Dissertation submitted to the Department of strategy and management at the Norwegian school of economics and business administration.

Brown, S. L., \& Eisenhardt, K. M. (1997). The art of continuous change: Linking complexity theory and time-paced evolution in relentlessly shifting organizations, Administrative Science Quarterly, 42: 1-34.

Bryson, J. M. (2004). Strategic planning for public and nonprofit organizations : a guide to strengthening and sustaining organizational achievement, (3rd ed). 
Dalton, G. W. (1970), Influence and organizational change. In G. Dalton, P. Lawrence, and L. Greiner (eds), organization change and Development. Homewood, III. Irwin.

Daft RL, Macintosh NB. (1981), A tentative exploration into the amount and equivocality of information processing in organizational work units. Administrative Science Quarterly 26: 207-24.

Daft RL, Weick KE. (1984). Toward a Model of Organizations as Interpretation Systems. Academy of Management Review 9(2): 284-95.

Denison DR, Dutton JE, Kahn JA, Hart SL. (1996). Organizational context and the interpretation of strategic issues: a note on CEOs' interpretations of foreign investment, Journal of Management Studies 33: 453-474.

Dutton JE, Ashford SJ. (1993). Selling issues to top management, Academy of Management, Review,18(3): 397-428.

Dunford, R., Jones, D. (2000). Narrative in strategic change, Human Relations, 53, 1207-26.

Dutton, J. e. (1988). "understanding strategic agenda building and its implications for managing change", in L. R. Pondy, R. J. Boland and H. Thomas (Eds) Managing Ambiguity and change (pp. 127-144). Chichester: John Wiley.

Dutton, J.E., Duncan R.B. (1987). The influence of the strategic planning process on strategic change, Strategic Management Journal 8 : 103-116.

Dutton JE, Duncan R.B. (1987). The creation of momentum for change through the process of strategic issue diagnosis. Strategic Management Journal 8: 279-295.

Dutton JE, Ottensmeyer E. (1987). Strategic issue management systems: forms, functions, and contexts, Academy of Management Review, 12: 355-365.

Dutton J., Dukerich, J., (1991), keeping an eye on the mirror: the role of image and identity in organizational adaption, Academy of management journal, 34, 517-554.

Dutton, J.E. (1993). The making of organizational opportunities: an interpretive, pathway to organizational change. Research in organizational Behavior, 15:195-226.

Dutton, J. E., Penner W. J. (1993). Organizational Identity and Strategic Agenda Building, J. Hendry and G. Johnson with J. Newton (Eds.) In Strategic Thinking: Leadership and the Management of Change, John Wiley \& Sons, Ltd., 89-113.

Dutton J.E., Fahey L., Narayan V.K. (1983). Toward Understanding Strategic Issue Diagnosis, Strategic Management Journal, 4(4): 30723

Dutton J.E., Duncan R.B. (1987). The creation of momentum for change through the process of strategic issue diagnosis. Strategic Management Journal 8: 279-295.

Dutton J.E., Ottensmeyer E. (1987). Strategic issue management systems: forms, functions, and contexts, Academy of Management Review 12: 355-365.

Dutton, J.E., Duncan R.B. (1987). The creation ofmomentum for change through the process of strategic issue diagnosis, Strategic Management Journal 8:279-295.

Dutton, J.E., Ashford S.J. (1993). Selling issues to top management, Academy of Management Review 18:397 -428.

Meyer, R.J.H. (2007), Mapping the Mind of the Strategist: A Quantitative Methodology for Measuring the Strategic Beliefs of Business Executives, Rotterdam: ERIM Research Foundation.

Dutton, J.E., Walton E.J., Abrahamson E. (1989). Important Dimensions of Strategic Issues: Separating the Wheat from the Chaf, Journal of Management Studies, Volume 26, Issue 4, pages 379-396.

Dutton, J. E., Stephen A. S., Wagner D. (1990). Diagnosing Strategic Issues and Managerial Investment of Resources. Advances in Strategic management, volume 6, pages 143-167.

Dutton J. E., Ashford S. J., O'Neill R. M., Lawrence K.A., (2001), Moves that matter: Issue selling and organizational change, The Academy of Management Journal, Vol. 44, No. 4 , pp. 716-736.

Gilbert CG., (2006), change in the presence of residual fit: can competing frames exist. Organization sience, 17(1): 150-167.

Glaser, B. G., (1978), Theoretical sensitivity: Advances in the methodology of grounded theory, Mill Valley, CA: The Sociology Press.

Fearon, C., Starr, S., \& McLaughlin, H. (2012). Blended learning in higher education (HE): conceptualising key strategic issues within a business school. Development and Learning in Organizations: An International Journal, 26(2), 19-22.

Hopkinson, G. C. (2001). Influence in marketing channels: a sense-making investigation,

Psychology and Marketing, 18, 423-44.

Huisman, M. (2001). Decision-making in meetings as talk-in-interaction, International Studies of Management and Organization, 31, 6990.

Heugens P. P. M. A. R. (2001). Strategic Issues Management: Implications for corporate Performance, Erasmus University: Rotterdam.

Jameson, D. A. (2001). Narrative discourse and management action, The Journal of Business Communication, 38, 476-511.

Kanter, R. M. (1982). The middle manager as innovator, Harvard Business Review, 60(4): 95-105.

Metcalfe, L. Desigining precarious partnership, In Nystrom, P. and W. Starbuk (eds), Handbook of organization Design, Oxford University Press, New York, 1981, 2, pp.503-530.

Kanter RM. (1982). The middle manager as innovator. Harvard Business Review 60(4): 95-105.

Kent D. M., Lin, Sh.J., (2014), Analogical reasoning for diagnosing strategic, strategic management journal issues in dynamic and complex environments, Wiley Online Library.

Kiesler S, Sproull L. (1982). Managerial Response to Changing Environments: Perspec-tives on Problem Sensing from Social Cognition, Administrative Science Quarterly 27(4): 548-70

Kuvaas B. (2002). An exploration of two competing perspectives on informational context in top management strategic issue interpretation, Journal of Management Studies 39: 977-1001. 
Kunnas, Peter, (2009), organizational attention and strategic issue management system performance, Dissertation for degree of Doctor of Science in technology, faculty of information and natural sciences at helsinki university of Technology

Lant, T.K., Milliken F.J., Batra B. (1992). The role ofmanagerialleaming and interpretation in strategic persistence and reorientation: An empirical exploration.

Mazzola P,. Kellermanns, F,. W,. 2010, Handbook of Research on Strategy Process, Edward Elgar Publishing Limited.

Meyer, AD. (1982). Adapting to environmental jolts, Administrative Science Quarterly 27:515-536.

Gooding, RZ., Kinicki A.J. (1995). Interpreting event causes: The complementary role of categorization and attribution processes, Journal of Management Studies 32 (1):1-22

Jackson, S.E., Dutton J.E. (1988). Discerning threats and opportunities, Administrative Science Quarterly 33:370-387.

Miller, K. D., \& Lin, S. J. (2014). Analogical reasoning for diagnosing strategic issues in dynamic and complex environments. Strategic Management Journal

Milliken FJ. (1990), "Perceiving and interpreting environmental change: an examination of college administrators' interpretation of changing demographics", Academy of Management Journal 33: 42-63.

Motii, B. B., \& Sanders, T. J. (2014). Strategic issues management and economic impact analysis: The case of Central State University. Journal of Case Research in Business and Economics Volume.

Plambeck N, Weber K. (2010). When the glass is half full and half empty: CEOs' ambivalent interpretations of strategic issues, Strategic Management Journal 31: 689-710.

Thomas JA, McDaniel RR Jr. (1990). Interpreting strategic issues: effects of strategy and the information-processing structure of top management teams, Academy of Management Journal 33: 286-306.

Thomas JB, Clark SM, Gioia DA. (1993). Strategic Sensemaking And Organizational Performance: Linkages Among Scanning, Interpretation, Action, And Outcomes, Academy of Management Journal 36(2): 239-70. 